\section{STATEMENT OF INTEREST}

None declared.

\section{REFERENCES}

1 Aldington S, Harwood M, Cox B, et al. Cannabis use and risk of lung cancer: a case-control study. Eur Respir J 2008; 31: 280-286.
2 Hashibe M, Morgenstern H, Cui Y, et al. Marijuana use and the risk of lung and upper aerodigestive tract cancers: results of a population-based case-control study. Cancer Epidemiol Biomarkers Prev 2006; 15: 1829-1834.

\title{
Noninvasive ventilation and the potential risk of transmission of infection
}

\section{To the Editors:}

In their exhaustive review on noninvasive ventilation (NIV) in acute respiratory failure, AMBROSINO and VAGHEGGINI [1] do not mention the potential risk of transmitting infections during its application.

Noninvasive positive-pressure ventilation (NPPV) is becoming increasingly used in patients with acute respiratory failure caused by a wide range of infectious aetiologies such as human-adapted avian influenza, aspergillosis and varicella [2-4], in order to avoid intubation or as a bridge to invasive mechanical ventilation. Substantial exposure to exhaled air occurs within a $0.5-\mathrm{m}$ radius of patients receiving NPPV at usual pressures (expiratory positive airway pressure $45 \mathrm{cmH}_{2} \mathrm{O}(0.39 \mathrm{kPa})$; inspiratory positive airway pressure $\left.1,215 \mathrm{cmH}_{2} \mathrm{O}(1.18 \mathrm{kPa})\right)$ : higher ventilator pressures result in a wider distribution of exhaled air [5]. Indeed, in the recently proposed World Health Organization interim guidelines on prevention and control of acute respiratory diseases in healthcare, NIV has been included among those aerosol-generating procedures in which the risk of pathogen transmission is still "controversial/possible" but not documented [6].

Furthermore, reusable equipment used in delivering NPPV may be exposed to potentially infectious material during routine use through contact with the patient's skin, mucousal membranes, respiratory secretions and blood. If this reusable equipment is not properly disinfected between patients it can lead to a major nosocomial transmission of a wide range of respiratory pathogens.

Reusable masks and exhalation valves should be disassembled into their component parts before undergoing an automated process utilising a combined washer/disinfector/drier that uses heat at a moderate but effective temperature; e.g. the Health Technical memorandum HTM2030 cycle which peaks at $87^{\circ} \mathrm{C}$ for $1 \mathrm{~min}$. Reusable tubing is difficult to decontaminate effectively using this method (because of the length and diameter of the lumen); however, it can be autoclaved at $134^{\circ} \mathrm{C}$ for $3.5 \mathrm{~min}$. Headgear and chinstraps should be treated in a washing machine with a cycle that reaches either $65^{\circ} \mathrm{C}$ for $10 \mathrm{~min}$ or $71^{\circ} \mathrm{C}$ for $3 \mathrm{~min}$. In most ventilators used for NIV there is no airflow from the patient back into the ventilator.
Hence, the risk of contamination of the ventilator is extremely low providing a bacterial filter is used and superficial cleaning of the ventilator between patients is satisfactory.

Healthcare workers should be aware of the potential risks of infection transmission during noninvasive positive-pressure ventilation, and should take stringent contact and droplet precaution.

\section{A. Singh* and P.J. Sterk ${ }^{\#}$}

*Pulmonary and Critical Care Medicine, Christian Medical College and Hospital, Chandigarh Road, Ludhiana, India.

"Lung Function Lab, Leiden University Medical Center, Leiden, The Netherlands.

\section{REFERENCES}

1 Ambrosino N, Vagheggini G. Noninvasive positive pressure ventilation in the acute care setting: where are we? Eur Respir J 2008; 31: 874-886.

2 Tran TH, Nguyen TL, Nguyen TD, et al. Avian influenza A (H5N1) in 10 patients in Vietnam. N Engl J Med 2004; 350: 1179-1188.

3 Antonelli M, Conti G, Bufi M, et al. Noninvasive ventilation for treatment of acute respiratory failure in patients undergoing solid organ transplantation: a randomized trial. JAMA 2000; 283: 235-241.

4 Sadovnikoff N, Varon J. CPAP mask management of varicella-induced respiratory failure. Chest 1993; 103: 1894 1895.

5 Hui DS, Hall SD, Chan MTV et al. Noninvasive positivepressure ventilation: an experimental model to assess air and particle dispersion. Chest 2006; 130: 730-740.

6 World Health Organization. Infection prevention and control of epidemic- and pandemic-prone acute respiratory diseases in health care. WHO Interim Guidelines. World Health Organization, 2007. www.who.int/csr/resources/publications/ WHO_CD_EPR_2007_6/en/ Date last accessed: April 4, 2008. Last updated: June 2007. 